\title{
Erratum to: Subtype analysis of Blastocystis isolates in Swedish patients
}

\author{
J. Forsell • M. Granlund • C. R. Stensvold • \\ C. G. Clark • B. Evengård
}

Published online: 27 April 2012

(C) Springer-Verlag 2012

\section{Erratum to: Eur J Clin Microbiol Infect Dis (2012)} DOI 10.1007/s10096-011-1416-6

The correct spelling of author's names \& complete affiliations are as follows:

J Forsell ${ }^{1}$, M Granlund1*, CR Stensvold ${ }^{2}$, CG Clark ${ }^{3}$, B Evengård $^{4}$

${ }^{1}$ Div Clinical Bacteriology, Dept Clinical Microbiology, Umeå University, SE-901 85 Umeå, Sweden
${ }^{2}$ Department of Microbiological Diagnostics, Statens Serum Institut, Artiellerivej 5, DK-2300 Copenhagen S, Denmark

${ }^{3}$ Department of Pathogen Molecular Biology, Faculty of Infectious and Tropical Diseases, London School of Hygiene and Tropical Medicine, London WC1E 7HT, UK.

${ }^{4}$ Div Infectious diseases, Dept Clinical Microbiology, Umeå University, SE-901 85 Umeå, Sweden

The online version of the original article can be found at http:// dx.doi.org/10.1007/s10096-011-1416-6

J. Forsell $\cdot$ M. Granlund $(\bowtie)$

Division of Clinical Bacteriology,

Department of Clinical Microbiology, Umeå University,

90185 Umeå, Sweden

e-mail: margareta.granlund@vll.se

C. R. Stensvold

Department of Microbiological Diagnostics,

Statens Serum Institut,

Artiellerivej 5,

2300 Copenhagen S, Denmark

C. G. Clark

Department of Pathogen Molecular Biology,

Faculty of Infectious and Tropical Diseases,

London School of Hygiene and Tropical Medicine,

London WC1E 7HT, UK

B. Evengård

Div Infectious diseases, Department of Clinical Microbiology,

Umeå University,

90185 Umeå, Sweden 